UDC 351.851:614.225

DOI https://doi.org/10.32840/1992-5786.2020.69-1.22

\author{
O. I. Pylypyshyn \\ Candidate of Historical Sciences (PhD), Associate Professor, \\ Assistant Professor of the Higher Education Pedagogy and Social Sciences Department Meeting \\ I. Ya. Horbachevsky Ternopil National Medical University
}

L. M. Lykha

MSN, Assistant Professor, Senior Laboratory Technician Department of Clinical Immunology, Allergology and General Patient Care

I. Ya. Horbachevsky Ternopil National Medical University

\title{
SOCIAL, ECONOMIC, HISTORICAL AND POLITICAL TRENDS AFFECTING THE ROLE OF NURSES EDUCATION
}

The article is devoted to the analysis of socio-economic, historical and other factors that influence the quality of nursing education. The globalization and integration of modern society, the recognition by the world community of the problem of physical, moral and social health as the main indicator of socio-economic maturity, culture and success of the state, social demand for the quality of medical services determine the special requirements for the professional activity of medical personnel.

It has proved that the nurse must have a thorough knowledge of clinical thinking, fundamental and specialized knowledge and skills in complex patient care, medical care, and proactive health care activities in accordance with the world professional standards, standards of professional morality and ethics that complies with the principle of humanity.

Nurses are considered to be informational intermediaries - persons, through whom the public receives some information about disease prevention and health promotion. And they can also significantly affect patients and their families to prevent illnesses. Due to educational activities, medical staff achieves competence and confidence in practice. Many challenges and opportunities are ahead for nurse's education in the delivery of health care as this nation moves forward in the XXI century. The foremost challenge for nurses is to be able to demonstrate, through research and action, that a definite link exists between education and positive behavioral outcomes of the learner. In this era of cost containment, government regulations, and healthcare reform, the benefits of patient and staff education must be made clear to the public, to healthcare employers, to healthcare providers, and to payers of healthcare benefits. To be effective and efficient, nurses must be willing and able to work collaboratively with other members of the healthcare team to provide consistently high-quality care to the patient. The responsibility and accountability of nurses for the delivery of care to the consumer can be accomplished, in part, through education based on solid principles of teaching and learning. The key to effective education for patients, families, and nursing staff is the nurse's understanding of and ongoing commitment to the role of educator.

Key words: education process, teaching, instruction, learning, patient education, staff education, barriers to education, obstacles to learning.

Problem statement. Patient education has long been considered a major component in the repertoire of standard care giving by the nurse. The role of the nurse as educator is deeply entrenched in the heritage and development of the profession. Since the mid-1800s, when nursing was first acknowledged as a unique discipline, the responsibility for teaching has been recognized as an important healthcare initiative assumed by nurses. The focus of teaching efforts by nurses was not only on the care of the sick, but also on educating other nurses for professional practice.

Florence Nightingale, the founder of modern nursing, was the ultimate educator.

Not only did she develop the first school of nursing, but she also devoted a large portion of her career to educating those involved in the delivery of health care. Nightingale taught nurses, physicians, and health officials about the importance of proper conditions in hospitals and homes to assist patients in maintaining adequate nutrition, fresh air, exercise, and personal hygiene to improve their well-being. By the early 1900 s, public health nurses in this country clearly understood the significance of education in the prevention of disease and in the maintenance of health (Chachkes \& Christ, 1996) [1].

For decades, then, patient teaching has been recognized as an independent nursing function. Nurses have always educated others - patients, families, and colleagues - and it is from these roots that nurses have expanded their practice to include the broader concepts of health and illness (Glanville, 2000) [2].

As early as 1918, the NationalLeagueof Nursing Education (NLNE) in the United States [now the National League for Nursing (NLN)] observed the importance of health teachingasa function within 
the scope ofnursingpractice. This organization recognizedtheresponsibility ofnursesforthepromotion of healthandtheprevention of illness in such settingsasschools, homes, hospitals, and industries. Two decades later, the NLNE declared that a nurse was fundamentally a teacher and an agentofhealth regardless of the setting inwhichpractice occurred (National League of Nursing Education, 1937) [3].

By 1950, the NLNE had identified course content dealing with teachings kills, developmental and educational psychology, and principles of the educational process of teaching and learning as areas in the curriculum common to all nursing schools (Redman, 1993). The implication was that nurses were tobe pre- pared, upon graduation from theirbasicnursing program, to assume the roleas teacherof others. The American Nurses Association has for years promulgated statements on the functions, standards, and qualifications for nursing practice, of which patient teaching is an integral aspect. In addition, the International Council of Nurses has long endorsed education for health as an essential requisite of nursing care delivery. Today, state nurse practice acts (NPAs) universally include teaching withinthescope of nursing practice responsibilities. Nurses are expected to provide instruction to consumers to assist them to maintain optimal levels of wellness, prevent disease, manage illness, and develop skills to give supportive care to family members. Nursing career ladders often incorporate teaching effectiveness as a measure of excellence in practice. The more recent development of clinical pathways, also referred to as critical pathways, has led to a popular, multidisciplinary approach to delineating predetermined client outcomes that are used to measure patient adherence to pathway expectations. Nurses are in the fore front of innovative strategies for the delivery of patient care. The teaching of patients and families as well as healthcare personnel is the means to accomplish the professional goals of providing cost-effective, safe, and high-quality care.

Presentation of the main material. In recognition of the importance of patient education by nurses, the Joint Commission on Accreditation of Healthcare Organizations (JCAHO) delineated nursing standards for patient education as early as 1993. These standards, which take the form of mandates, are based on descriptions of positive outcomes of patient care. They are to be met through teaching activities by nurses that must be patient and family oriented. Required accreditation standards have provided the impetus for nursing service managers to put greater emphasis on unit-based clinical education activities for staff to improve nursing interventions relating to patient education for the achievement of this client out comes (Mc Goldrick., 1994) [4].

More recently, JCAHO has expanded its expectations to include an interdisciplinary team approach in the provision of patient education as well as evidence that patients and their significant others understand what they have been taught. This requirement means that providers must consider the literacy level, educational background, language skills, and culture of every client during the education process (Davidhizar \& Brownson, 1999) [5]. In addition, the Patient's Bill of Rights, firstdevelopedinthe1970s by the American Hospital Association and adopted by hospitals nationwide, has established the rights of patients to receive complete and current information concerning diagnosis, treatment, and prognosis in terms they can reasonably be expected to understand.

In 1995, the Pew Health Professions Commission, influenced by the dramatic changes currently surrounding health care, published a broad set of competencies that it believes will mark the success of the health professions in the twenty-first century. Most recently, the Commission (1998) released a fourth report as a follow-up on health professional practice in the new millennium. Numerous recommendations to the health professions have been proposed by the Commission. More than one half of them pertain to the importance of patient and staff education and to the role of the nurse as educator. Among the recommendations, the Commission has addressed the need to:

- Provide clinically competent and coordinated care to the public

- Involve patients and their families in the decision-making process regarding health interventions

- Provide clients with education and counseling on ethical issues

- Expand public access to effective care

- Ensure cost-effective and appropriate care for the consumer

- Provide for prevention of illness and promotion of healthy lifestyles for all people.

Accomplishing the goals and meeting the expectations of these organizations calls for a redirection of education efforts. Over time,the role of the nurse as educator has undergone a paradigm shift. In patient education, the provider teaching role has evolved from what once was a disease-oriented approach to a more prevention-oriented approach. Nowand in the future, the focus will be on teaching for the promotion and maintenance of health. Since the 1980s, greater recognition has been given to client education as a healthcare activity. Once done as part of discharge plans at the end of hospitalization, patient education efforts have expanded to become integrated into a comprehensive plan of care that occurs throughout the healthcare delivery process (Davidhizar \& Brownson, 1999) [5]. As described by Grueninger (1995) [6], this transition toward wellness has entailed a progression "fromdis- ease-oriented 
patient education (DOPE) to prevention-oriented patient education (POPE) to ultimately become health-oriented patient education (HOPE)". This metamorphosis has changed the role of educator from one of wise healer to expert advisor/teacher to facilitator of change. Instead of the traditional aim of simply imparting information, the emphasis is now on empowering patients to use their potentials, abilities, and resources to the fullest (Glanville, 2000) [7]. Presently, the demand for nurses in the role of educators of patients, their families, and the general publicis rapidly accelerating.

Also, the role of today's educator is one of "training the trainer" - that is, preparing nursing staff through continuing education, in-service programs, and staff development to maintain and improve their clinical skills and teaching abilities. The key to the success of our profession is for nurses to teach other nurses. We are the primary educators of our fellow colleagues and other healthcare staff personnel. In addition, the demand for educators of nursing students is at an all-time high. It is essential that professional nurses be pre- pared to effectively perform teaching services that meet the needs of many individuals and groups in different circumstances across a variety of practice settings.

In addition to the professional and legal standards put forth by various organizations and agencies, there has arisen an increasing emphasis on nurses' potential role in teaching activities as a result of social, economic, and political trends nationwide affecting the public's health. The following are some of the significant forces affecting nursing practice in particular and the healthcare system in general (Jorgensen, 1994; McGinnis, 1993 [8]; Latter et al., 1992 [9]; Kellmer-Langan et al., 1992 [10]; DeSilets, 1995 [11]; Wilkinson, 1996 [12]; Glanville, 2000 [2]; Birchenall, 2000 [13]):

- The federal government, through health- care reform initiatives, has established national health goals and objectives for the future. Healthy People 2010: National Promotion and Disease Prevention Objectives (U.S. Department of Health and Human Services, 2000 [14]) is a document that describes national needs in relation to health promotion and disease prevention for the public. Objectives include the development of effective health education programs to assist individuals to recognize and change risk behaviors, to adopt or maintain protective health practices, and to make appropriate use of healthcare delivery systems. Achievement of these national objectives would dramatically cut healthcare costs, prevent the premature onset of disease and disability, and help all Americans lead healthier and more productive lives. Nurses, as the largest group of healthcare professionals, embody the professional philosophy of holistic care and are capable of making a real difference in educating people so that they can attain and maintain healthy lifestyles.

- The growth of managed care, the shifts in payer coverage, and the issue ofreimbursement for the provision of health care have placed an increasingly greater emphasis on outcome measures, achievable primarily through success of patient education efforts.

- Health providers are beginning to recognize the economic and social values in practicing preventive medicine through health education initiatives.

- Political emphasis is on productivity, competitiveness in the marketplace, and costcontainment measures to restrain health- service expenses. Politicians and healthcare administrators alike acknowledge the importance of health education as a requisite to accomplishing these economic goals in today's society.

- The healthcare reform movement is opening up new avenues for expansion of preventive and promotion education efforts directed at communities, schools, and workplaces in addition to the traditional care settings.

- There is concern on the part of healthcare professionals regarding the legal pressures associated with malpractice and disciplinary action for incompetency. In recent years, continuing education, either by legislative mandate or as a requirement of the employing institution, has come to theforefront as a potential answer to the challenge of ensuring the competency of practitioners. Continuing education has emerged asa response to the change and expansion of knowledge in the nursing profession. It is a means to transmit new knowledge and skills as well as to reinforce or refresh previously acquired knowledge and abilities, thereby guaranteeing the continuing growth of staff nurse competencies.

- The interest that continues to be exhibited by nurses in defining their own role, body of knowledge, scope of practice, and professional expertise has focused on patienteducation as central to the practice ofnursing.

- Consumers are demanding increased knowledge and skills about how to care for themselves and how to prevent disease. A rise in consumerism in health-service provision is paralleling the interest exhibited in other aspects of consumer involvement in the marketplace. As people are becoming more aware of and more knowledgeable about healthcare matters, theyare questioning the nature of their impairments and needs and are demanding a greater understanding of treatments and goals. The healthcare trends of the 1990s, which emphasized consumer rights and responsibilities, will continue in the twenty-first century. Such trends have already increased the demand for patient and consumer 
information services, and these demands are expected to intensify in thefuture.

- Demographic trends - namely, the aging of the population - are requiring an emphasis to be placed on self-reliance and maintenance of a healthy status over an extended life span. The percentage of the U.S. population older than 65 years will climb dramatically in the next 20 to 30 years as the baby boom generation of the post - World War II era reaches the late adulthood years. The baby boomers' health needs will become greater as they deal with degenerative illnesses and other effects of the aging process.

- Among the major causes of morbidityand mortality are those diseases now recognized as being lifestyle-related and preventable through educational interventions.

- The proportionate increase in the incidence of chronic and incurable conditions necessitates that individuals and families become informed participants to manage their own illnesses.

- Advanced technology is increasing the complexity of care and treatment as well as diverting large numbers of patients from inpatient healthcare settings to community-based settings. Life support and maintenance technologies are enabling patients to carry on with their lives away from the acute, direct care-giving arenas. Patient education is necessary toassistthem to independently follow through with self-management activities.

- Earlier hospital discharge is forcing patients and their families to be more self reliant while managing their own illnesses. Patient teaching can facilitate an individual's adaptive responses to illness.

- There is a belief on the part of nurses and other healthcare providers, which is supported by research, that patient education improves compliance and, hence, health and well-being. Better understanding by clients of their treatment plans can lead to increased cooperation with therapeutic regimens. Patient education will enable them to independently solve problems encountered outside the protected care environments of hospitals, thereby increasing their independence.

- There is an increased proliferation in the number of self-help groups established to support clients in meeting their physical and psychosocial needs. The success of these support groups and behavioral change programs has led to an upsurge in public interest as well as nurse involvement and advocacy for these educational endeavors.

These examples are indicative of the major trends operating in this country to create a climate of increased consumer and professional expectations. Nurses recognize the need to develop their expertise in teaching to keep pace with the demands of patient and staff education. In turn, nurses are in a key position to carry out health education. They are the healthcare providers who have the most continuous contact with patients and families, are usually the most accessible source of information for the consumer, and are the mosthighly trusted of all health professionals. In a recent Gallup poll, nurses were ranked first in honesty and ethics among 45 occupations (Mason, 2001 [15]). Patient teaching is becoming an increasingly important function within the scope of nursing practice.

Current and continuously improving patient and staff education programs are an integral part of today's system of health care delivery to the public. The purpose of patient education is to increase the competence and confidence of clients for selfmanagement. Our goal is to support patients through the transition from being invalids to being independent in care; from being dependent recipients to being involved participants in the care process; and from being passive listeners to active learners. The single most important action of nurses as care givers is to prepare patients and their families for self-care. If clients cannot independently maintain or improve their health status when on their own, we have failed to help them reach their potential.

In light of cost-containment measures by healthcare agencies and despite the sometimes scarce resources available, nurses continue to pursue the goals of involving patients in exploringandexpandingtheirself-careabilities through interactive patient education efforts (Mc Goldricket al., 1994 [4]; Glanville, 2000 [7]). The benefits of effective patient education are many. Patient education has demonstrated its potentialto:

- Increase consumer satisfaction

- Improve quality of life

- Ensure continuity of care

- Decrease patient anxiety

- Effectively reduce the incidence of complications of illness

- Promote adherence to healthcare treatment plans.

In turn, the educator role of nurses enhances their job satisfaction when they recognize that their teaching actions have the potential to forge therapeutic relationships with patients, allow for greater patient - nurse autonomy, increase their account- ability for practice, and create change that really makes a difference in the lives of others.

Because an estimated $80 \%$ of all health needs and problems are handled at home, there truly does exist a need to educatepeople on how to care for themselves - both to get well and to stay well (Health ServicesMedical Corporation, 1993 [16]). Illness is a natural life process, but so is mankind's ability to learn. Along with the ability to learn comes a natural curiosity that allows people to view new and difficult situations as challenges rather than as defeats. As Robin Orr [17] (1990) noted, "Illness can become 
an educational opportunity $<\ldots$. > a'teachable moment' when ill health suddenly encourages [patients] to take a more active role in their care". Numerous studies have documented the fact that informed patients are more likely to comply with medical treatment plans and find innovative ways to cope with illness. Such individuals are also better able to manage symptoms of illnessand are less likely to experience complications. Overall, patients are more satisfied with care when they receive adequate information about how to manage for themselves. One of the most frequently cited complaints by patients in litigation cases is that they were not adequately informed.

Just as the need exists for teaching clientsto help them become participants and informed consumers to achieve independence in self-care, the need also exists for staff nurses to be exposed to up-todate and ongoing information with the ultimate goal of enhancing their practice. The purpose of staff education is to increase the competence and confidence of nurses to function independently in providing quality care to the consumer. Nurses play a key role in improving the nation's health, and they recognize the importance of lifelong learning to keep their knowledge and skills current (De Silets, 1995 [11]).

Our primary aims, then, as educators should be to nourish clients as well as mentor staff. We must value education and make it a priority for both our patients and our fellow colleagues.

The education process is a systematic, sequential, planned course of action consisting oftwo major interdependent operations, teaching and learning. This process forms a continuous cycle that also involves two interdependent players, the teacher and the learner. Together, they jointly perform teaching and learning activities, the outcome of which leads to mutually desired behavior changes. These changes foster growth in the learner and, it should be acknowledged, growth in the teacher as well. Thus, the education process should always be a participatory, shared approach to teaching and learning.

The education process has always been compared to the nursing process - rightly so, because the steps of each process run parallel to one another, although they have different goals and objectives. The education process, like the nursing process, consists of the basic elements of assessment, planning, implementation, and evaluation. The nursing process and the education process are logical, scientifically-based frameworks for nursing. Both processes provide a rational basis for nursing practice rather than an intuitive one. They aremethods for monitoring and judging the overall quality of nursing interventions based on objective data and scientific criteria. The two are different in that the nursing process focuses on the planning and implementation of care based on the assessment and diagnosis of the physical and psychosocial needs of the patient, whereas the education process identifies instructional content and methods based on an assessment and prioritization of the client's learning needs, readiness to learn, and learning styles. The outcomes of the nursing process are achieved when the physical and psychosocial needs of the client are met. The outcomes of the education process are achieved when changes in knowledge, attitudes, and skills occur. Both processes are ongoing, with assessment and evaluation perpetually redirecting the planning and implementation phases of the processes. Ifmutually agreed-on outcomes in either process are not achieved, as determined by evaluation, then the nursing process or the education process can and should begin again through reassessment, replanning, and reimplementation.

It should be noted that the actual act of teaching is merely one component of the education process. Education, as the broad umbrella process, includes the acts ofteaching and instruction. Teaching is a deliberate intervention that involves the planning and implementation of instructional activities and experiences to meet intended learner outcomes according to a teaching plan. Instruction, a term often used interchangeably with teaching, is one aspect of teaching. It is a component of teaching that involves the communicating of information about a specific skill in the cognitive, psychomotor, or affective domain. Teaching and instruction are often formal, structured, organized activities prepared days in advance, but they can be performed informally on the spur of the moment during conversations or incidental encounters with the learner. Whether formal orinformal, planned well in advance or spontaneous, teaching and instruction are nevertheless deliberate and conscious acts with the objective of producing learning.

Conclusion. The fact that teaching and instruction are intentional does not necessarily mean that theyhave to be lengthy and complex tasks, but itdoes mean that they comprise conscious actions on the part of the teacher in responding to an individual's need to learn. The cues that someone has a need to learn can be communicated in the form of a verbal request, a question, a puzzled or confused look, or a gesture of defeat or frustration. In the broadest sense, then, teaching is a highly versatile strategy that can beapplied in preventing, promoting, maintaining, or modifying a wide variety of behaviors in a learner who is receptive, motivated, and adequately informed (Redman, 1971 [18]; Duffy, 1998 [19]). Learning is defined as a change in behavior (knowledge, skills, and attitudes) that can occur at any time or in any place as a resultof exposure to environmental stimuli. Learning is an action by which knowledge, 
skills, and attitudesare consciously or unconsciously acquired such that behavio risaltered in some way that can be observed or measured.

The success of the nurse educator's endeavors at teaching is measured not by how much content has been imparted, but rather by how much the person has learned. Specifically, patient education is a process of assisting people to learn health-related behaviors (knowledge, skills, attitudes, and values) so that they can incorporate those behaviors intoeveryday life. As stated previously, the purpose of patient education is to assist clients to achieve the goal of optimal health and independence in self-care.

Staff education, by contrast, is the process of influencing the behavior of nurses by producing changes in their knowledge, attitudes, values, and skills. As stated previously, the purpose here is to help nurses maintain and improve their competencies as required for the delivery of quality care to the consumer. Both patient and staff education involve forging a relationship betweenlearner and educator so that the learner's information needs (cognitive, psychomotor, and affective) can be met through the process of education.

A useful paradigm to assist nurses to organize and carry out the education process is the ASSURE model (Rega, 1993 [20]). The acronym stands for:

- Analyzelearner.

- Stateobjectives.

- Select instructional methods andtools.

- Use teachingmaterials.

- Require learner performance.

\section{References:}

1. Chachkes E., Christ G. Cross cultural issues in patient education. Patient Education \& Counseling, 1996. 27. P. 13-21.

2. Glanville I.K. Moving towards health oriented patient education (HOPE). Holistic Nursing Practice. 2000. 14 (2). P. 57-66.

3. National League of Nursing Education. $A$ Curriculum Guide for Schools of Nursing. New York : The League, 1937.

4. Mc Goldrick T.K., Jablonski R.S., Wolf Z.R. Needs assessment for a patient education program in a nursing department: A delphi approach. Journal of Nursing Staff Development. 1994. 10 (3). P. 123-130.
5. Davidhizar R.E., Brownson K. Literacy, cultural diversity, and client education. Health Care Manager. 1999. 18 (1). P. 39-47.

6. Grueninger U.J. Arterial hypertension: Lessons from patient education. Patient Education and Counseling. 1995. 26. P. 37-55.

7. Glanville I.K. Moving towards health oriented patient education (HOPE). Holistic Nursing Practice. 2000. 14 (2). P. 57-66.

8. McGinnis J.M. The role of patient education in achieving national health objectives. Patient Education and Counseling. 1993. 21. P. 1-3.

9. Health education in nursing: Perceptions of practice in acute settings / S. Latter et al. Journal of Advanced Nursing. 1992. 17. P. 164-172.

10.Kellmer-Langan D.M., Hunter C., Nottingham J.P. Knowledge retention and clinical application after continuing education. Journal of Nursing Staff Development. 1992. 8 (1). P. 5-10.

11. De Silets L.D. Assessing registered nurses' reasons for participating in continuing education. Journal of Continuing Education in Nursing. 1995. 26 (5). P. 202-208.

12.Wilkinson J.M. The C word: A curriculum for the future. Nursing \& HealthCare. 1996. 17 (2). P. 72-77.

13.Birchenall P. Nurse education in the year 2000: Reflection, speculation and challenge. Nurse Education Today. 2000. 20. P. 1-2.

14.U.S. Department of Health and Human Services. Healthy People 2010: Objectives for Improving Health. Washington DC : U.S. Government Printing Office, 2000. V. II.

15. Mason D. Promoting health literacy: Patient teaching is a vital nursing function. American Journal of Nursing. 2001. 101 (2). P 7.

16. Health Services Medical Corporation, Inc. Wealth in wellness begins "Selfwise." Worksite Well news. 1993. 1 (3). P. 1.

17. Orr R. Illness as an educational opportunity. Patient Education and Counseling. 1990. 15. P. 47-48.

18.Redman B.K. Patient education as a function of nursing practice. Nursing Clinics of North America. 1971. 6 (4). P. 573-580.

19.Duffy B. Get ready - Get set - Go teach. Home Healthcare Nurse. 1998. 16 (9). P. 596-602.

20.Rega M.D. Amodel approach for patient education. MEDSURG Nursing. 1993. 2 (6). P. 477-479, 495.

Пилипишин О. І., Лиха Л. М. Соціальні, економічні, історичні та політичні тенденції, які впливають на роль навчання медичних сестер

Стаття присвячена аналізу соціально-економічних, історичних та інших чинників, що впливають на якість навчання медичних сестер. Глобалізація та інтеграція сучасного суспільства, визнання світовою спільнотою проблеми фрізичного, морального і соціального здоров'я як головного показника соціально-економічної зрілості, культури й успішності держави, соціальний запит на якість медичних послуг зумовлюють особливі вимоги до профресійної діяльності медичного персоналу.

Доведено, що медична сестра повинна досконало володіти клінічним мисленням, фундаментальними і спеціальними знаннями й уміннями щодо комплексного догляду за пацієнтами, наданням медичної допомоги, активного здійснення профрілактичної діяльності у сфрері охорони здоров'я відповідно 
до світових профресійних стандартів, норм професійної моралі та етики, що відповідає принципу гуманності.

Медсестер вважають інфоормаційними посередниками - особами, завдяки яким громадськість отримує певну інфоормацію щодо профрілактики захворювань та зміцнення здоров'я. А також вони суттєво можуть вплинути на пацієнтів та членів їхніх сімей, щоб запобігти захворюванням. Завдяки освітній діяльності медичний персонал набуває компетентності та впевненості у практиці. Багато викликів та завдань постає перед медичною сестрою на шляху отримання освіти в галузі надання медичної допомоги, оскільки нація рухається вперед у XXI столітті.

Першочерговим завданням для медсестер є можливість продемонструвати, завдяки дослідженню, певний зв'язок між навчанням та позитивними результатами їхньої поведінки у певній ситуації. У теперішню епоху обмеження витрат, урядових нормативно-правових актів та реформи охорони здоров'я переваги навчання пацієнтів та персоналу повинні бути зрозумілі громадськості, роботодавцям у галузі охорони здоров'я, постачальникам медичних послуг та тим, хто оплачує надання медичних послуг. Для того, щоб бути корисними та успішними, медсестри повинні бути готовими вміти співпрацювати з іншими членами медичного колективу, щоб забезпечити стабільно якісну допомогу пацієнту. Відповідальність та підзвітність медсестер за надання допомоги пацієнтам може бути досягнута частково через освіту, яка базується на стійких принципах навчання та виховання. Запорукою ефективного виховання пацієнтів, сімей та медперсоналу є фраховість медичної сестри та постійне зобов'язання щодо ролі вихователя.

Ключові слова: навчальний процес, викладання, інструктування, навчання, виховання пацієнтів, освіта персоналу, бар'єри у навчанні, перешкоди у навчанні. 